\title{
Age of grassy strips influences biodiversity of ground beetles in organic agro-ecosystems
}

\author{
Mazhar Ranjha, Ulrich Irmler \\ Institute for Ecosystem Research, Department of Applied Ecology, University of Kiel, Kiel, Germany; \\ Corresponding Author: mranjha@ecology.uni-kiel.de, uirmler@ecology.uni-kiel.de
}

Received 19 February 2013; revised 20 March 2013; accepted 15 April 2013

Copyright (C) 2013 Mazhar Ranjha, Ulrich Irmler. This is an open access article distributed under the Creative Commons Attribution License, which permits unrestricted use, distribution, and reproduction in any medium, provided the original work is properly cited.

\begin{abstract}
The following investigations were conducted to evaluate grassy strips of different age for organic arable fields. From September 2009 to October 2010, adult ground beetles were sampled by pitfall traps in three grassy strips (2, 4, and 9 years old), their adjacent cropping areas, their field edges, and a control field (age 0 ) in Schleswig-Holstein, northern Germany. Carabid assemblages were similar among the fields, strips and edges. Grassy strips and edges had higher species richness and lower activity density than the control field. Activity density increased with increasing distance from the field edge in grassy strips and in the adjacent fields. In cropping areas, species richness and Shannon's $H$ increased with increasing age of strips, whereas evenness and activity density decreased with increasing distance from the field edges. Compared to carnivorous and phytophagous carbides, omnivorous species were affected less by age of strips and distance from field margins. In the strips, species richness of the dominant species increased with age and decreased with distance, but the effect of strip age on species richness was still found in more than $150 \mathrm{~m}$ from the margin. A positive effect of the age of grassy strips on species richness was found for cropping fields, grassy strips and field edges. Old grassy strips also exerted greater influence on the species richness and biodiversity of the adjacent arable fields than the younger strips.
\end{abstract}

Keywords: Organic Agriculture; Carabidae; Biodiversity; Grassy Strips

\section{INTRODUCTION}

The loss of biodiversity in Europe is mainly linked to the after-effects of the intensification of agriculture and the removal of natural habitats [1]. In order to reduce its drastic effects in the future, sustainable intensification of agriculture and the conservation of the biodiversity are recommended for food security [2]. The natural and semi-natural habitats adjacent to the arable fields are important sources of a diverse fauna and support the colonization of arthropods when the fields are empty after the harvest [3]. Among these habitats, grassy strips are considered to function as corridors for dispersal [4], source of food [5], refuge during field work phases [6], and overwinter sites for beneficial insects [7]. Their vegetation diversity supports the insect diversity and density in the adjacent arable fields [8]. After destruction of these habitats, large field areas demand their reconstruction for the invasion of predators into the fields $[4,9]$.

Among the soil-dwelling predators, the ground beetles (Carabidae) are used as biological indicators because of their diversity, well-known ecology and taxonomy, sensitivity to biotic and abiotic factors, relevance at multiple spatial scales and their ample collection without difficulty for analysis [10]. They consume weed seeds [11], prey on pests [12], and have an integral position in the food web [13].

It has been found in many investigations that organic farming supports beneficial insects [14]. For the conservational strategies and the biological control in organic agriculture, the establishment or augmentation of seminatural habitats are recommended [15]. Several reports have shown the effect of distance from the natural habitats on ground beetles [16,17]. Most of the investigations on the positive effects of grassy strips on carabids were executed under conventional agriculture. Recent studies show that the carabid fauna under organic farming in arable field centres resemble that of field margins [18]. 
Few investigations have been executed concerning influence of age of grassy strips on biodiversity [35]. Therefore, this study focuses on the combined effects of age and length of grassy strips as determining factors on biodiversity of arable fields. Thus, the following questions should be answered: 1) have grassy strips beneficial effects on carabids in organic farming? 2) Does biodiversity change with the distance from field edges? 3) Do older grassy strips support biodiversity better than the younger ones and 4) can we predict the combined effects of age and distance on the species richness in grassy strips and adjacent fields?

\section{MATERIAL AND METHODS}

\subsection{Experimental Area and Sampling Design}

The following investigation was performed from September 2009 to October 2010 in four organic arable fields: two in "Panten" and two on the adjacent "Hof Ritzerau", Schleswig-Holstein, Northern Germany. The distance between the two locations was approximately 1 $3 \mathrm{~km}$. The climate of the area is moderate with $685.5 \mathrm{~mm}$ rainfall and $8.1^{\circ} \mathrm{C}$ mean yearly temperature over a 30 year period. The soil type is sandy loam [19].

Three of the selected fields had grassy strips and one was chosen to be the control field. Two grassy strips, 2and 4-year-old, were in "Panten" and the 9-year-old grassy strip was in "Hof Ritzerau". All the grassy strips were approximately $3 \mathrm{~m}$ wide and established and managed in the same way during their development. The grassy strips were established as "beetle banks" [4,9], but grass vegetation dominated already in the second year. Original seed mixture contained ten herb species and few grass species, e.g., Hordeum vulgare L. However, already in the second year all strips were dominated by the main grass species, i.e., Lolium perenne L., Poa trivialis L., and Elymus repens (L.) Gould. Both grass coverage and species richness ranged between $60 \%-70 \%$ and $50-$ 60 species, respectively, and represented the typical grassy vegetation in moderately moist sites of northern Germany [20]. All field edges were characterized by woods or hedges and a grassy strip in front of them adjacent to the field with the same vegetation as in the established grassy strips. Wheat crop was sown in the fields.

Adjacent to each grassy strip, one cropping area (4and 9 -year-old) or two cropping areas (2-year-old) were investigated. The definition "cropping area" was selected for the arable field adjacent to the grassy strips to distinguish it from the control field (without grassy strip). Adult ground beetles were collected by using pitfall traps: glass jars, half filled with $90 \%$ glycol and a surface tension reducing agent. The traps were covered with trans- parent plastic plates elevated by two iron strips fixed into the soil to protect the traps from rain and birds.

Three traps were installed on each field edge. Furthermore, two lines of pitfall traps were installed: one in the arable field and one in the grassy strip. The traps of the two lines were in $30 \mathrm{~m}$ distance intervals beginning from the field edges. In the control field $50 \mathrm{~m}$ intervals were chosen due to the long distance between the field edges (Table 1). The distance between the two lines of traps was $30 \mathrm{~m}$. Due to the narrow width of the grassy strips, only two replicate pitfall traps were installed in each row per $30 \mathrm{~m}$ interval in approximately $1.5 \mathrm{~m}$ distance from each other. The calculations were based on the distance to the nearest field edge, so the fields with two field edges (2- and 4-year-old fields and control field) provided two sets of traps for each distance. Pitfall traps were generally changed at monthly intervals, except in winter (December-March). However, sampling periods were not consistent because of agronomic activities. All beetles were identified up to species level according to [21].

\subsection{Data Analysis}

The activity density of carabids was calculated in individuals (ind.) 100 trap days $^{-1}$ for further analysis. Species richness was measured by 1) total number of species per trap, 2) sample-rarefaction method and 3) species number needed for $90 \%$ of dominance. For the last parameter, the species were ordered in decreasing order of dominance and the number of species needed to get $90 \%$ of the total specimens was taken. This parameter was selected because the capture efficiency of traps in arable

Table 1. Number of pitfall traps in the four age groups (zero, two, four, nine) and the four habitats (Edge $=0 \mathrm{~m}, \mathrm{G}=$ grassy strip, $\mathrm{C}=$ cropping area, $\mathrm{F}=$ control area).

\begin{tabular}{cccccccccc}
\hline Age & Two & Four & Nine & \multicolumn{4}{c}{ Zero (Control) } \\
\hline $\begin{array}{c}\text { Habitat } \\
\text { Distance (m) }\end{array}$ & G & C & G & C & G & C & Total & $\begin{array}{c}\text { Distance } \\
(\mathrm{m})\end{array}$ & F \\
Edge & & 6 & & 6 & & 3 & 15 & Edge & 3 \\
30 & 4 & 8 & 4 & 4 & 2 & 2 & 24 & 50 & 4 \\
60 & 4 & 8 & 4 & 4 & 2 & 2 & 24 & 100 & 4 \\
90 & 4 & 8 & - & - & 2 & 2 & 16 & 150 & 4 \\
120 & 4 & 8 & - & - & 2 & 2 & 16 & 200 & 4 \\
150 & 4 & 8 & - & - & 2 & 2 & 16 & 250 & 4 \\
180 & - & - & - & - & 2 & 2 & 4 & 300 & 4 \\
- & - & - & - & - & - & - & - & 350 & 4 \\
- & - & - & - & - & - & - & - & 400 & 4 \\
Total & 20 & 40 & 8 & 8 & 12 & 12 & 115 & & 32 \\
\hline
\end{tabular}


fields is higher than in grassland or forests [22] and to avoid effects by accidental species. The biodiversity was determined by Shannon's H and evenness.

The assemblages of the carabids in different habitats were compared by the Detrended Correspondence Analysis (DCA). In the DCA, the traps of the cropping areas, strips, and field edges of each of the three fields and of the control field were combined into one sample.

To compare differences in the activity density, species richness, Shannon's H, and evenness among the four habitats (field edges, grassy strips, cropping areas, and control field), nested ANOVA was performed, where all the individual traps were nested within the habitats. Due to the unavailability of more grassy strips of the same age in the selected region, we executed the experiment without replication. According to the problems with nonreplicated experimental designs [23], nested ANOVA was used. Each grid of two traps was combined to one sample. Therefore, the grids at the same distance from the two field edges were considered to be two samples. Similarly, the three traps of each field edge were used as one sample.

While analysing the effect of age of grassy strips, the control field used was a 0 -year-old strip, since strips are usually ploughed after 2 years and established at another place. The effects of age and distance were analysed using multiple linear regression after testing the data on normal distribution. For the analysis of feeding groups, carabids were classified, according to their feeding habits $[24,25]$, into three groups, i.e. carnivorous, omnivorous and phytophagous. To find the effect of strips on the cropping areas, only the values of the cropping area traps in a distance of more than $30 \mathrm{~m}$ from the field edges were used in order to omit the edge effect. The statistical analyses were performed using the program STATISTICA [26]. For DCA and the calculations of biodiversity indices and rarefaction, the PAST program [27] was used.

\section{RESULTS}

\subsection{Faunal Composition and Assemblages}

A total of 23,146 ground beetles $(11,068$ in Panten, 12,078 in Hof Ritzerau) was found which were classified into 89 species (67 in Panten, and 74 in Hof Ritzerau) (Table 2). The following ten most abundant species contributed $85 \%$ to the total amount: Pterostichus melanarius (19.3\%), Poecilus cupreus (18.2\%), Anchomenus dorsalis (10.8\%), Bembidion lampros (6.4\%), Harpalus affinis (6.2\%), Pseudoophonus rufipes (5.7\%), Nebria brevicollis (5.3\%), Carabus auratus (4.8\%), Bembidion tetracolum (4.5\%), and Trechus quadristriatus (3.8\%). In the control field, field edges, grassy strips, and adjacent cropping areas, 51, 57, 62, and 63 species, respectively, were found. Classification on feeding habits showed the following order: carnivorous (45 species) $>$ phytophagous ( 20 species) $>$ omnivorous ( 7 species).

The four habitats were weakly separated according to the Detrended Correspondence Analysis with an eigenvalue of 0.33 on the first axis (Figure 1). The lowest similarity was shown between the edge site of the 9year-old strip and the control field, although they both were located on Ritzerau farm. Strips and cropping areas formed no separate clusters, but cropping sites exhibited a stronger similarity than strip sites.

Activity density was the highest in the control field for all carabids, carnivorous, and omnivorous species, but it was the highest in the grassy strips for the phytophagous species (Table 3). In general, the lowest activity density was found in field edges. Species richness, determined as the number of species per trap, was also the lowest in the field edges, whereas it was also lowest in grassy strips for carnivorous species. However, phytophagous species showed the lowest species richness in the control field. In contrast to species richness, diversity determined by Shannon's $\mathrm{H}$ was the highest in the field edges or the grassy strips. Evenness was the lowest in the control area, except for phytophagous species.

\subsection{Effect of Distance and Age of Grassy Strips on Adjacent Fields}

The results of the multiple linear regressions showed that either age or distance had an impact on the various diversity values and activity density, except for species richness of the phytophagous carabids that was affected by both parameters (Table 4). Omnivorous species showed the lowest effects by the two parameters. Overall, Shannon's $\mathrm{H}$ was mainly correlated with age, whereas evenness and activity density were mainly correlated with distance. This means that the Shannon's diversity in the cropping field increased with an increase in age, whereas evenness decreased with distance from field edge. In the cropping field, the correlation coefficients were usually closer than in the grassy strips.

The number of species needed for $90 \%$ of total specimens decreased from field edge to strip centre in all strips regardless of age (Figure 2). Multiple regression revealed significant results for both age $(\mathrm{r}=0.56)$ and distance $(\mathrm{r}=0.57)(\mathrm{F}=15.3, \mathrm{DF}=2.18, \mathrm{p}<0.01)$. These two factors explained $63 \%$ of the variability $(\mathrm{r}=0.79)$. The steepest decrease occurred close to the field edge, while a more or less steady state was reached at $30 \mathrm{~m}$ to $60 \mathrm{~m}$ distance from field edge.

The higher species richness in the cropping area near the 9-year-old strip was also found by the sample rarefaction method. According to this method, the species richness was highest in the cropping area near the 9- 
Table 2. Total activity density of the carabids in the four habitats and the age classes of the grassy strips $(0$ indicates the control field, 2, 4 and 9 the age (years) of the strips); feedings habits (Feed. habit): $\mathrm{C}=$ Carnivorous, $\mathrm{O}=$ Omnivorous, $\mathrm{P}=\mathrm{Phytophagous}$.

\begin{tabular}{|c|c|c|c|c|c|c|c|c|c|c|c|c|c|}
\hline \multirow{2}{*}{$\begin{array}{c}\text { Habitat } \\
\text { Species/Age }\end{array}$} & \multirow{2}{*}{$\begin{array}{l}\text { Feed. } \\
\text { habit }\end{array}$} & \multicolumn{4}{|c|}{ Field edges } & \multicolumn{3}{|c|}{ Grassy strips } & \multirow[b]{2}{*}{0} & \multicolumn{3}{|c|}{ Cropping areas } & \multirow[t]{2}{*}{ Total } \\
\hline & & 0 & 2 & 4 & 9 & 2 & 4 & 9 & & 2 & 4 & 9 & \\
\hline Pterostichus melanarius & $\mathrm{C}$ & 39 & 38 & 8 & 11 & 320 & 6 & 96 & 2330 & 1362 & 38 & 215 & 4463 \\
\hline Poecilus cupreus & $\mathrm{O}$ & 16 & 2 & 9 & 4 & 349 & 9 & 490 & 1688 & 1111 & 52 & 482 & 4212 \\
\hline Anchomenus dorsalis & $\mathrm{C}$ & 16 & 82 & 2 & 16 & 104 & 6 & 76 & 1176 & 715 & 185 & 120 & 2498 \\
\hline Bembidion lampros & $\mathrm{C}$ & 6 & 11 & 7 & . & 212 & 8 & 55 & 242 & 662 & 164 & 120 & 1487 \\
\hline Harpalus affinis & $\mathrm{O}$ & 14 & 17 & 7 & 6 & 205 & 11 & 160 & 473 & 257 & 87 & 210 & 1447 \\
\hline Pseudoophonus rufipes & $\mathrm{O}$ & 14 & 47 & 24 & 2 & 139 & 40 & 17 & 74 & 814 & 129 & 21 & 1321 \\
\hline Nebria brevicollis & $\mathrm{C}$ & 32 & 46 & 9 & . & 69 & 19 & 35 & 58 & 703 & 32 & 223 & 1226 \\
\hline Carabus auratus & $\mathrm{C}$ & . & 12 & 28 & 1 & 118 & 109 & 48 & 18 & 646 & 71 & 65 & 1116 \\
\hline Bembidion tetracolum & $\mathrm{C}$ & 142 & 14 & . & 7 & 29 & 14 & 55 & 561 & 110 & 10 & 103 & 1045 \\
\hline Trechus quadristriatus & $\mathrm{C}$ & 33 & 7 & 6 & 35 & 14 & 19 & 63 & 200 & 91 & 132 & 271 & 871 \\
\hline Poecilus versicolor & $\mathrm{C}$ & 4 & 2 & 4 & 5 & 58 & 2 & 227 & 5 & 270 & 7 & 75 & 659 \\
\hline Amara similata & $\mathrm{O}$ & 1 & 1 & . & 4 & 218 & 4 & 9 & 232 & 21 & 34 & 30 & 554 \\
\hline Agonum muelleri & $\mathrm{C}$ & 14 & . & 2 & 1 & 6 & 2 & 17 & 259 & 26 & 3 & 98 & 428 \\
\hline Carabus nemoralis & $\mathrm{O}$ & 7 & 5 & 38 & 16 & 4 & 25 & 83 & 10 & 33 & 3 & 16 & 240 \\
\hline Calathus fuscipes & $\mathrm{C}$ & . & 5 & . & 0 & 15 & . & 3 & 51 & 89 & 5 & 3 & 171 \\
\hline Clivina fossor & $\mathrm{C}$ & . & . & 7 & 0 & 19 & 14 & 3 & 31 & 29 & 30 & 12 & 145 \\
\hline Amara aenea & $\mathrm{P}$ & . & 5 & 1 & 1 & 18 & . & 32 & 10 & 14 & 6 & 37 & 124 \\
\hline Amara familiaris & $\mathrm{P}$ & . & 3 & 2 & 1 & 60 & . & 5 & 3 & 21 & 22 & 5 & 122 \\
\hline Bembidion properans & $\mathrm{C}$ & 1 & . & . & . & . & . & 25 & 42 & 1 & 3 & 42 & 114 \\
\hline Carabus granulatus & $\mathrm{C}$ & 3 & 4 & . & . & 7 & 2 & 10 & 9 & 56 & 7 & 2 & 100 \\
\hline Other species (69) & & 22 & 33 & 17 & 72 & 49 & 31 & 69 & 251 & 126 & 46 & 81 & 803 \\
\hline Total (89) & & 364 & 340 & 171 & 182 & 2013 & 321 & 1578 & 7723 & 7157 & 1066 & 2231 & 23,146 \\
\hline
\end{tabular}

year-old strip, intermediate in the cropping area of the 4year-old strip and lowest in the cropping areas of 2year-old strip (Figure 3).

Using the $90 \%$ level of species richness, significant correlations were also exhibited for cropping areas (Figure 3). The number of dominant species in the cropping areas increased with increasing age of strips. Cropping areas adjacent to the 9-year-old strip had on average three species more than the control field representing age 0 in the succession. In the control field, the difference between field and edge was small, with 2 species on average, but difference increased with increasing age.

If the $30 \mathrm{~m}$ distance traps were omitted to focus on the effect of the strips on the cropping areas, the activity density showed no difference among the three cropping areas for all carabids, carnivorous, and omnivorous spe- cies except the phytophagous carabids with higher activity density in the cropping areas near the 4- and 9-yearold strips than in the 2-year-old strip (Table 5). For omnivorous and phytophagous carabid species, species richness exhibited significantly higher values in the cropping area near the 9-year-old strip than in the two other areas. A similar pattern was found when the diversity was determined by Shannon's H. The cropping area near the 9- or 4-year-old strip revealed higher values than the cropping area near the 2-year-old strip. This was true for all carabids, carnivorous, and phytophagous species, whereas Shannon's H for the omnivorous species was equal in all three cropping areas. The results for evenness were mostly insignificant. Only carnivorous species had lower evenness in the cropping area near the 2-year-old strip than that near the 9-year-old strip. 
Table 3. Mean activity density (ind. 100 trap $\cdot$ days $^{-1}$ ), species richness, Shannon $(\mathrm{H})$, and evenness in the different habitats for all species and three feeding groups; different exponent characters $\left({ }^{\mathrm{a}},{ }^{\mathrm{b}},{ }^{\mathrm{c}},{ }^{\mathrm{d}}\right)$ ) show significant differences found by LSD test at $\mathrm{p}<0.001$; ${ }^{1}$ median instead of mean, NS: not significant; $F_{D F}$, Gradient.

\begin{tabular}{|c|c|c|c|c|c|c|c|c|c|}
\hline \multirow[t]{2}{*}{ Habitat } & \multicolumn{2}{|c|}{ Control } & \multicolumn{2}{|c|}{ Cropping areas } & \multicolumn{2}{|c|}{ Grassy strips } & \multicolumn{2}{|c|}{ Field edges } & \multirow[t]{2}{*}{$\mathrm{F}_{3,78}$} \\
\hline & Mean & S.D. & Mean & S.D. & Mean & S.D. & Mean & S.D. & \\
\hline \multicolumn{10}{|l|}{ All species } \\
\hline Activity density ${ }^{1}$ & a 85.1 & & b65.3 & & ${ }^{\mathrm{c}} 48.47$ & & ${ }^{\mathrm{d}} 11.04$ & & 149.4 \\
\hline Species richness & ${ }^{\mathrm{a}} 17.60$ & 0.10 & a 17.40 & 3.14 & ${ }^{\mathrm{a}} 16.52$ & 3.53 & ${ }^{\mathrm{b}} 14.44$ & 4.23 & 8.7 \\
\hline Shannon $(\mathrm{H})$ & ${ }^{\mathrm{b}} 2.03$ & 0.22 & a2 2.27 & 0.18 & a 2.27 & 0.23 & a 2.23 & 0.29 & 12.6 \\
\hline Evenness & ${ }^{\mathrm{d}} 0.44$ & 0.10 & ${ }^{\mathrm{c}} 0.57$ & 0.09 & ${ }^{\mathrm{b}} 0.61$ & 0.11 & ${ }^{\mathrm{a}} 0.68$ & 0.13 & 32.6 \\
\hline \multicolumn{10}{|l|}{ Carnivorous } \\
\hline Activity density ${ }^{1}$ & ${ }^{\mathrm{a}} 58.93$ & & ${ }^{b} 33.34$ & & ${ }^{\mathrm{c}} 13.45$ & & ${ }^{\mathrm{d}} 7.64$ & & 165.3 \\
\hline Species richness & ${ }^{\mathrm{a}} 11.53$ & 1.59 & ${ }^{\mathrm{a}} 10.82$ & 1.71 & ${ }^{\mathrm{b}} 9.85$ & 2.39 & ${ }^{\mathrm{b}} 9.11$ & 3.01 & 10.3 \\
\hline Shannon $(\mathrm{H})$ & ${ }^{\mathrm{b}} 1.60$ & 0.27 & ${ }^{\mathrm{a}} 1.88$ & 0.20 & ${ }^{\mathrm{a}} 1.82$ & 0.32 & ${ }^{\mathrm{a}} 1.79$ & 0.32 & 9.3 \\
\hline Evenness & c 0.45 & 0.12 & ${ }^{\mathrm{b}} 0.62$ & 0.11 & ${ }^{\mathrm{ab}} 0.66$ & 0.13 & a 0.72 & 0.17 & 28.5 \\
\hline \multicolumn{10}{|l|}{ Omnivorous } \\
\hline Activity density ${ }^{1}$ & a 26.74 & & ${ }^{\mathrm{b}} 13.33$ & & ${ }^{\mathrm{c}} 10.20$ & & ${ }^{\mathrm{d}} 2.30$ & & 91.2 \\
\hline Species richness & ${ }^{\mathrm{a}} 4.66$ & 0.97 & ${ }^{b} 4.18$ & 0.95 & ${ }^{b} 4.15$ & 0.70 & $c^{c} 3.28$ & 1.02 & 11.2 \\
\hline Shannon $(\mathrm{H})$ & ${ }^{\mathrm{b}} 0.95$ & 0.23 & ${ }^{\mathrm{b}} 1.00$ & 0.17 & a 1.12 & 0.20 & ${ }^{\mathrm{b}} 0.94$ & 0.36 & 6.1 \\
\hline Evenness & c 0.58 & 0.13 & ${ }^{\mathrm{b}} 0.68$ & 0.15 & a 0.76 & 0.14 & ${ }^{\mathrm{a}} 0.83$ & 0.11 & 20.0 \\
\hline \multicolumn{10}{|l|}{ Phytophagous } \\
\hline Activity density ${ }^{1}$ & ${ }^{\mathrm{c}} 0.39$ & & ${ }^{\mathrm{b}} 0.84$ & & ${ }^{\mathrm{a}} 1.12$ & & ${ }^{\mathrm{c}} 0.29$ & & 17.9 \\
\hline Species richness & c 0.96 & 0.74 & ${ }^{\mathrm{ab}} 1.93$ & 1.30 & aа 2.26 & 1.5 & ${ }^{\mathrm{bc}} 1.40$ & 1.06 & 11.3 \\
\hline Shannon $(H)$ & ${ }^{\mathrm{b}} 0.14$ & 0.31 & ${ }^{\mathrm{a}} 0.56$ & 0.48 & ${ }^{\mathrm{a}} 0.63$ & 0.52 & ${ }^{\mathrm{a}} 0.41$ & 0.41 & 10.7 \\
\hline Evenness & 0.75 & 0.44 & 0.78 & 0.36 & 0.76 & 0.35 & 0.72 & 0.45 & NS \\
\hline
\end{tabular}

\section{DISCUSSION}

In the Detrended Correspondence Analysis, very low eigenvalues depict a close similarity in the species composition of the different habitats. The close relationships among carabid assemblages of arable fields were already stressed $[28,29]$. In our study, even the similarity between field edges and arable fields was high. The highest differences along the first canonical axis were found between the control field and the field edges. The organic practices are an explanation for this high similarity. After a six year period of organic farming, [18] found that the species diversity of field centres resembles that of field edges. They also emphasised that the number of species occurring only in field edges under conventional farming increases in field centres of organic arable fields.

We found higher activity densities in arable fields than in the grassy strips, as documented in many studies $[30,31]$. However, higher activity densities were also re- ported for grassy structures or flower strips in comparison to arable fields $[11,32]$. The higher activity density of the control field and the cropping areas may be due to the open ground surface. When compared to grassland or forests, a significantly higher mobility of species is found in arable fields [22]. The higher activity density in the arable fields in comparison to the field edges or grassy strips is, therefore, contributed to the greater mobility of species and not to their higher population density. Since the ratio between density and activity of species is undetermined for the different habitats, it is assumed that activity density is not an efficient factor for evaluating the ecological processes.

The lowest biodiversity was measured in the control field. Higher diversities were found in the field edges and the grassy strips, which illustrate that carabids benefit from undisturbed habitats even under organic practices. Their higher biodiversity can be contributed to the stable and diverse environment and better food availabil- 
Table 4. Results of the multiple linear regressions using age and distance parameters; Const.: constant, Dist.: distance; r: correlation coefficient; " significantly $(<0.05)$ affected by parameter(s); p: refers to model with both parameters.

\begin{tabular}{|c|c|c|c|c|c|c|c|c|c|c|}
\hline & \multicolumn{5}{|c|}{ Field; DF $(2,18)$} & \multicolumn{5}{|c|}{ Strip; DF $(2,18)$} \\
\hline & Const. & Age & Dist. & $\mathrm{r}$ & $\mathrm{p}$ & Const. & Age & Dist. & $\mathrm{r}$ & $\mathrm{p}$ \\
\hline \multicolumn{11}{|l|}{ All species } \\
\hline Species richness & 15.08 & ${ }^{*} 0.49$ & 0.31 & 0.58 & 0.020 & 14.44 & ${ }^{*} 0.44$ & 0.31 & 0.54 & 0.04 \\
\hline Shannon's H & 2.20 & ${ }^{*} 0.66$ & -0.26 & 0.71 & 0.002 & 2.25 & 0.34 & -0.28 & 0.44 & NS \\
\hline Evenness & 0.63 & 0.30 & ${ }^{*}-0.67$ & 0.74 & 0.001 & 0.69 & -0.09 & ${ }^{*}-0.63$ & 0.63 & 0.01 \\
\hline Activity density & 29.12 & -0.06 & ${ }^{*} 0.66$ & 0.66 & 0.006 & 25.44 & -0.25 & ${ }^{*} 0.54$ & 0.59 & 0.02 \\
\hline \multicolumn{11}{|l|}{ Carnivorous } \\
\hline Species richness & 9.52 & 0.28 & 0.44 & 0.52 & NS & 8.80 & 0.41 & 0.34 & 0.53 & 0.04 \\
\hline Shannon's H & 1.63 & ${ }^{*} 0.87$ & 0.10 & 0.88 & 0.001 & 1.59 & ${ }^{*} 0.83$ & 0.14 & 0.84 & 0.001 \\
\hline Evenness & 0.58 & ${ }^{*} 0.70$ & -0.30 & 0.76 & 0.001 & 0.60 & ${ }^{*} 0.47$ & -0.24 & 0.53 & NS \\
\hline Activity density & 21.95 & -0.13 & ${ }^{*} 0.67$ & 0.60 & 0.004 & 19.79 & -0.40 & 0.41 & 0.57 & 0.03 \\
\hline \multicolumn{11}{|l|}{ Phytophagous } \\
\hline Species richness & 0.72 & ${ }^{*} 0.75$ & ${ }^{*} 0.31$ & 0.81 & 0.001 & 0.71 & ${ }^{*} 0.50$ & 0.33 & 0.60 & 0.02 \\
\hline Shannon's H & 0.17 & ${ }^{*} 0.70$ & 0.24 & 0.74 & 0.001 & 0.16 & ${ }^{*} 0.52$ & 0.23 & 0.57 & 0.03 \\
\hline Evenness & 0.56 & ${ }^{*} 0.53$ & 0.34 & 0.63 & 0.010 & 0.51 & 0.28 & 0.36 & 0.45 & NS \\
\hline Activity density & 0.22 & ${ }^{*} 0.69$ & 0.13 & 0.70 & 0.002 & 0.51 & 0.41 & 0.36 & 0.55 & NS \\
\hline \multicolumn{11}{|l|}{ Omnivorous } \\
\hline Species richness & 3.92 & 0.20 & 0.24 & 0.31 & NS & 3.92 & -0.10 & 0.44 & 0.45 & NS \\
\hline Shannon's H & 1.06 & 0.14 & -0.41 & 0.43 & NS & 1.16 & -0.20 & -0.33 & 0.38 & NS \\
\hline Evenness & 0.78 & -0.10 & ${ }^{*}-0.58$ & 0.59 & 0.02 & 0.86 & -0.17 & ${ }^{*}-0.62$ & 0.65 & 0.008 \\
\hline Activity density & 10.74 & -0.12 & ${ }^{*} 0.56$ & 0.57 & 0.03 & 9.16 & -0.17 & ${ }^{*} 0.57$ & 0.59 & 0.02 \\
\hline
\end{tabular}

ity $[5,33,34]$.

Our findings that species richness and diversity increased with the age of strips are supported in some other investigations $[7,35,36]$. However, it must be taken into account that local conditions and the number of accidental species can produce a high variability. The significant increase of the dominant species with age of the grassy strips points out the general importance of age for the biodiversity of the habitats investigated. In particular, carnivorous species benefit from older grassy strips. The importance of older field margins for the predatory fauna is shown by a better predator-prey ratio and parasitism than in younger margins [37]; the younger habitats have shorter food chains and simpler food-webs than the older habitats [16].

Distance from field edges plays an important role in the overall biodiversity of arable fields. In our investigation, species richness of the most dominant species (accumulated $90 \%$ of specimens) in grassy strips increased with an increase in age and decreased with increasing distance from the field edge. In contrast, activity density increased in both cropping areas and grassy strips with increasing distance from the field margin.

No significant decline was seen in the species richness of carabids with an increase in distance from the boundary hedge [38]. However, in another study species richness decreased with increasing distance from the field margin, whereas activity density showed no change at the distances of $30 \mathrm{~m}$ and $250 \mathrm{~m}$ [39]. They [39] could not find significant differences of species richness between the fields with and without strips at different distances, whereas the results of [40] documented increasing arthropod diversities from the cropping areas to the near hedge cropping area and strip in intensively managed arable fields. According to [16], the population of the arthropods decreases with increasing distance from grassy strips. The effect of distance can be based on the size of the species; the activity density of small carabids 


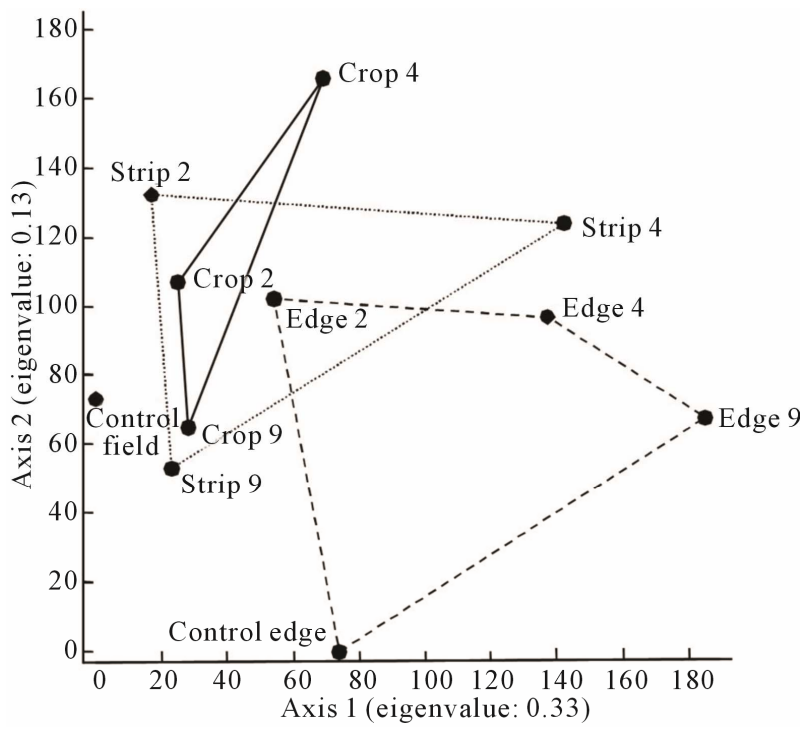

Figure 1. The first two axes of the Detrended Correspondence Analysis show four habitats (control, grassy strips, cropping areas, and field edges). Suffix 2, 4 and 9 with strip, field edge and crop refers to the habitats related to the 2-, 4-, and 9year-old grassy strips.

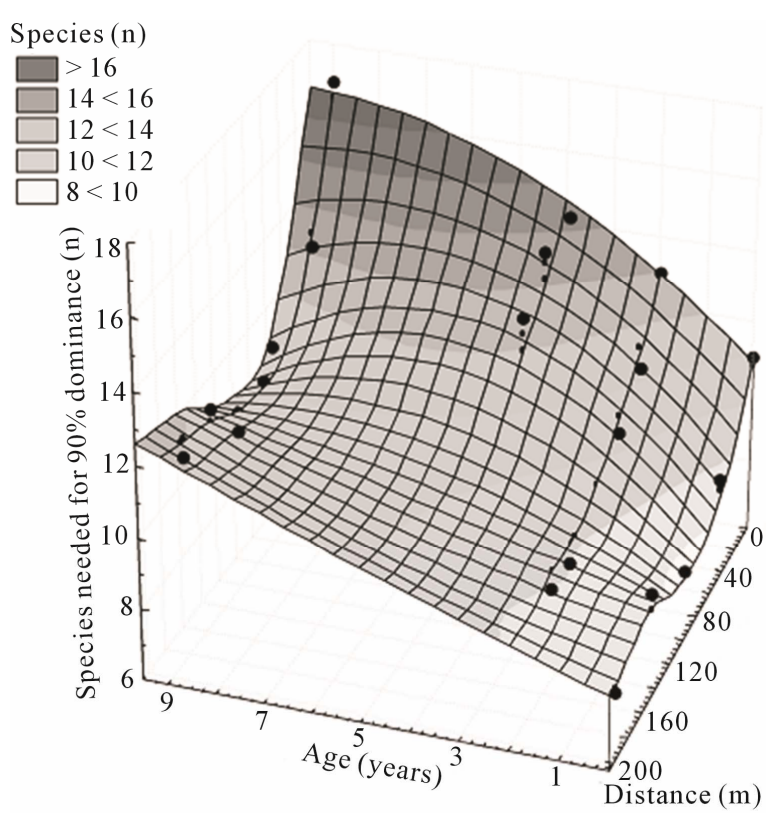

Figure 2. Number of species needed for $90 \%$ of total specimens in strips in relation to strip age and distance from the field edge.

decreased, while that of large carabids increased from the field margins [41]. Although the overall results are contradictory, the arthropod diversity decreases from the field edge to the field centre in many investigations. The significant differences in the abundance of the carabids at different distances were also related to the prey availability [42].

Our findings that older grassy strips promote species richness in adjacent arable fields are supported by [43],
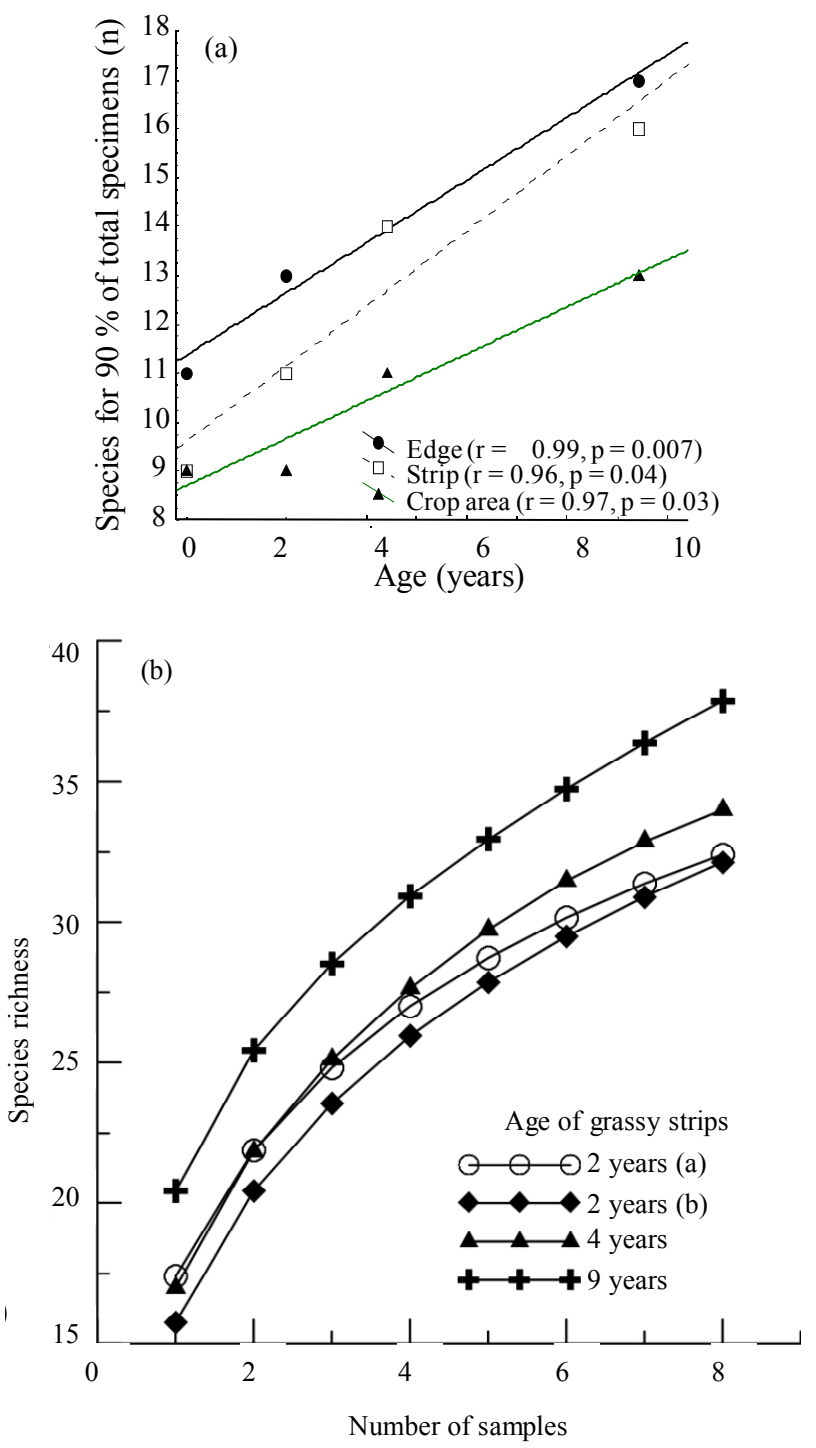

Figure 3. Number of species that account for at least $90 \%$ dominance (a) and species richness of sample rarefaction on crop areas near grassy strips of different ages (b).

who found a higher species richness in the cereals between the weed strips than inside the arable field without weed strips. In contrast to [43], our investigation revealed no significant influence of the grassy strips on the overall activity density in the adjacent field. The grassy strips have no influence on the population of the macrofauna in the nearby fields [38], whereas [39] documented an increase in the abundance of the carabids in the arable fields near grassy field margins. The positive effect of grassy strips on the biodiversity in arable fields has been documented in many studies $[8,17,30]$. The landscapes with large areas of grassland increase diversity of carabids in soybean fields [44]. The close relationship between landscape and the biodiversity of farmland was also stressed [45]. Our results concerning the significant correlation between age of grassy strips and the species 


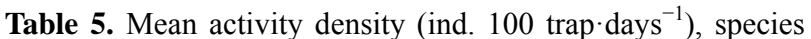
richness, Shannon $(\mathrm{H})$, and evenness for all species and the three feeding groups in the central cropping areas; different exponent characters $\left({ }^{\mathrm{a}},{ }^{\mathrm{b}},{ }^{* *},{ }^{* * *}\right)$ show significant differences found by LSD test; NS: not significant; $\mathrm{F}_{\mathrm{DF}}$, Gradient .

\begin{tabular}{|c|c|c|c|c|c|c|c|}
\hline \multirow[t]{2}{*}{ Age } & \multicolumn{2}{|c|}{ Two } & \multicolumn{2}{|c|}{ Four } & \multicolumn{2}{|c|}{ Nine } & \multirow[b]{2}{*}{$\mathrm{F}_{2,23}$} \\
\hline & Mean & S.D. & Mean & S.D. & Mean & S.D. & \\
\hline \multicolumn{8}{|l|}{ All species } \\
\hline Activity density $^{1}$ & 51.7 & & 39.8 & & 69.3 & & NS \\
\hline Species richness & ${ }^{\mathrm{a}} 17.60$ & 0.10 & ${ }^{\mathrm{a}} 17.40$ & 3.14 & ${ }^{\mathrm{a}} 16.52$ & 3.53 & ${ }^{* *} 8.06$ \\
\hline Shannon $(\mathrm{H})$ & ${ }^{\mathrm{b}} 2.20$ & 0.16 & ${ }^{\mathrm{a}} 2.41$ & 0.18 & a2.47 & 0.17 & ${ }^{* * *} 10.84$ \\
\hline Evenness & 0.55 & 0.10 & 0.59 & 0.05 & 0.09 & 0.11 & NS \\
\hline \multicolumn{8}{|l|}{ Carnivorous } \\
\hline Activity density $^{1}$ & 36.00 & & 26.25 & & 47.23 & & NS \\
\hline Species richness & 10.94 & 1.62 & 12.00 & 0.82 & 11.20 & 0.95 & NS \\
\hline Shannon $(\mathrm{H})$ & ${ }^{\mathrm{b}} 1.83$ & 0.17 & ${ }^{\mathrm{ab}} 1.95$ & 0.23 & ${ }^{\mathrm{a}} 2.11$ & 0.13 & ${ }^{* *} 10.39$ \\
\hline Evenness & ${ }^{\mathrm{b}} 0.59$ & 0.10 & ${ }^{\mathrm{ab}} 0.60$ & 0.12 & ${ }^{\mathrm{a}} 0.71$ & 0.07 & ${ }^{* *} 6.76$ \\
\hline \multicolumn{8}{|l|}{ Omnivorous } \\
\hline Activity density ${ }^{1}$ & 14.7 & & 13.3 & & 19.65 & & NS \\
\hline Species richness & b 3.9 & 0.82 & ${ }^{\mathrm{ab}} 4.00$ & 0.82 & ${ }^{\mathrm{a}} 4.90$ & 1.2 & ${ }^{*} 4.40$ \\
\hline Shannon $(\mathrm{H})$ & 0.96 & 0.16 & 1.08 & 0.23 & 0.99 & 0.16 & NS \\
\hline Evenness & 0.70 & 0.16 & 0.75 & 0.10 & 0.59 & 0.14 & NS \\
\hline \multicolumn{8}{|l|}{ Phytophagous } \\
\hline Activity density ${ }^{1}$ & ${ }^{\mathrm{b}} 0.67$ & & ${ }^{\mathrm{a}} 1.40$ & & ${ }^{\mathrm{a}} 1.71$ & & ${ }^{* * *} 20.82$ \\
\hline Species richness & ${ }^{\mathrm{b}} 1.69$ & 1.33 & ${ }^{\mathrm{ab}} 2.50$ & 1.29 & a 3.20 & 0.92 & **6.97 \\
\hline Shannon $(\mathrm{H})$ & ${ }^{\mathrm{b}} 0.48$ & 0.51 & ${ }^{\mathrm{ab}} 0.66$ & 0.51 & ${ }^{\mathrm{a}} 0.96$ & 0.35 & 4.68 \\
\hline Evenness & 0.76 & 0.41 & 0.88 & 0.12 & 0.85 & 0.11 & NS \\
\hline
\end{tabular}

richness in field edges indicate that not only the arable fields benefit from old grassy strips, but also the adjacent semi-natural habitats.

\section{ACKNOWLEDGEMENTS}

We are thankful to the owners and managers of farm Lämmerhof in Panten, Detlef Hack and Ute Thode, and the farm Ritzerauhof, Günther Fielmann, to get the permission for the investigation. Additionally we thank the Higher Education Commission of Pakistan for financial assistance.

\section{REFERENCES}

[1] Krebs, R.J., Wilson, J.D., Bradbury, R.B. and Siriwardena, G.M. (1999) The second silent spring? Nature, 400, 611612. doi: $10.1038 / 23127$
[2] Green, R.E., Cornell, S.J., Scharlemann, J.P.W. and Balmford, A. (2005) Farming and the fate of wild nature. Science, 307, 550-555. doi:10.1126/science. 1106049

[3] Tscharntke. T. and Kruess, A. (1999) Habitat fragmentation and biological control. In: Hawkins, B.A. and Cornell, H.V., Eds., Theoretical Approaches to Biological Control, Cambridge University Press, Cambridge, 190205.

[4] Thomas, M.B., Wratten, S.D. and Sotherton, N.W. (1991) Creation of island habitats in farmland to manipulate populations of beneficial arthropods: Predator densities and emigration. Journal of Applied Ecology, 28, 906-917. doi: $10.2307 / 2404216$

[5] Bommarco, R. (1998) Reproduction and energy reserves of a predatory carabid beetle relative to agroecosystem complexity. Ecological Applications, 8, 846-853. doi:10.1890/1051-0761(1998)008[0846:RAEROA]2.0.C $\underline{\mathrm{O} ; 2}$

[6] Asteraki, E.J., Hank, C.B. and Clements, R.O. (1995) The influence of different types of grassland field margin on carabid beetle (coleoptera, carabidae) communities. Agriculture, Ecosystems and Environment, 54, 195-202. doi:10.1016/0167-8809(95)00596-K

[7] Frank, T. and Reichhart, B. (2004) Staphylinidae and carabidae overwintering in wheat and sown wildflower areas of different age. Bulletin of Entomological Research, 94, 209-217. doi:10.1079/BER2004301

[8] Varchola J.M. and Dunn, J.P. (2001) Influence of hedgerow and grassy field borders on ground beetle (coleoptera: carabidae) activity in fields of corn. Agriculture, Ecosystems and Environment, 83, 153-163. doi:10.1016/S0167-8809(00)00249-8

[9] Thomas, M.B. Wratten, S.D. and Sotherton, N.W. (1992) Creation of island habitats in farmland to manipulate populations of beneficial arthropods: Predator densities and species composition. Journal of Applied Ecology, 29, 524-531. doi:10.2307/2404521

[10] Koivula, M. (2011) Useful model organisms, indicators, or both? Ground beetles (coleoptera, carabidae) reflecting environmental conditions. ZooKeys, 100, 287-317. doi: $10.3897 /$ zookeys. 100.1533

[11] Gaines H.R. and Gratton, C. (2010) Seed predation increases with ground beetle diversity in a Wisconsin (USA) potato agroecosystem. Agriculture, Ecosystems and Environment, 137, 329-336. doi:10.1016/j.agee.2010.03.003

[12] Bohan, D.A., Bohan, A.C., Glen, D.M., Symondson, W.O.C., Wiltshire, C.W. and Hughes, L. (2000) Spatial dynamics of predation by carabid beetles on slugs. Journal of Animal Ecology, 69, 367-379. doi:10.1046/j.1365-2656.2000.00399.x

[13] Thiele, H.-U. (1977) Carabid beetles in their environments: A study on habitat selection by adaptations in physiology and behaviour. Springer-Verlag, Berlin. doi:10.1007/978-3-642-81154-8

[14] Bengtsson, J., Ahnström, J. and Weibull, A. (2005) The effects of organic agriculture on biodiversity and abundance: A meta-analysis. Journal of Applied Ecology, 42, 261-269.

[15] Zehnder, G., Gurr, G.M., Kühne, S.M., Wade, R., Wratten, 
S.D. and Wyss, E. (2007) Arthropod pest management in organic crops. Annual Review of Entomology, 52, 57-80. doi:10.1146/annurev.ento.52.110405.091337

[16] Denys, C. and Tscharntke, T. (2002) Plant-insect communities and predator-prey ratios in field margin strips, adjacent crop fields, and fallows. Oecologia, 130, 315-324. doi:10.1007/s004420100796

[17] Kiss, J., Kádár, F., Kozma, E. and Tóth, I. (1993) Importance of various habitats in agricultural landscape related to integrated pest management: A preliminary study. Landscape Urban Plan, 27, 191-198. doi:10.1016/0169-2046(93)90049-J

[18] Schröter, L. and Irmler, U. (2013) Organic cultivation reduces barrier effect of arable fields on species diversity. Agriculture, Ecosystems and Environment, 164, 176-180. doi:10.1016/j.agee.2012.09.018

[19] Reiss, S., Bork, H.-R., Hoernes, U., Rinker, A. and Mitusov, A. (2008) Die verbreitung der böden auf den ackerflächen von hof ritzerau. Fauistisch-Ökologische Mitteilungen, 35, 59-73.

[20] Roweck, V.H. (2008) Die aktuelle und potenzielle floristische diversität der feldfluren auf hof ritzerau. Fauistisch-Ökologische Mitteilungen, 35, 103-122.

[21] Müller, G.-M. (2004) Adephaga I carabidae (laufkäfer). In: Freude, H., Harde, K.W., Lohse G.A. and Klausnitzer, B., Eds., Die Käfer Mitteleuropas, München, Elsevier, p. 521.

[22] Wallin, H. and Ekbom, B.S. (1988) Movements of carabid beetles (coleoptera:carabidae) inhabiting cereal fields: A field tracing study. Ecologia, 77, 39-43.

[23] Hurlbert, S.H. (1984) Pseudoreplication and the design of ecological field experiments. Ecolgical Monographs, 54, 187-211. doi: $10.2307 / 1942661$

[24] Lindroth, C.H. (1992) The ground-beetles (carabidae) of fennoscandia. A zoogeographic study. Part I. Specific knowledge regarding the species. Amerind Publishing, New Delhi.

[25] Warner, D.J., Allen-Williams, L.J. Warrington, S., Ferguson, A.W. and Williams, I.H. (2008) Implications for conservation biocontrol of spatio-temporal relationships between carabid beetles and coleopterous pests in winter oilseed rape. Agricultural and forest Entomology, 10, 375-387. doi:10.1111/j.1461-9563.2008.00391.x

[26] StatSoft, Inc. STATISTICA for Windows [Software-System for Data analysis] Version 6, 2004. http://www.statsoft.com

[27] Ø. Hammer, Harper, D.A.T. and Ryan, P.D. (2001) PAST: Paleontological statistics software package for education and data analysis. Palaeont Electronica, 4, 1-9.

[28] Irmler, U. (2003) The spatial and temporal pattern of carabid beetles on arable fields in northern Germany (Schleswig-Holstein) and their value as ecological indicators. Agriculture, Ecosystem and Environment, 98, 141-151. doi:10.1016/S0167-8809(03)00076-8

[29] Weibull, A. Östman, Ö. and Granqvist, Å. (2003) Species richness in agroecosystems: The effect of landscape, habitat and farm management. Biodiversity and Conservation, 12, 1335-1355. doi:10.1023/A:1023617117780
[30] Kromp, B. and Steinberger, K. (1992) Grassy field margins and arthropod diversity: A case study on ground beetles and spiders in eastern Austria (Coleoptera: Carabidae; Arachnida: Aranei, Opiliones). Agriculture, Ecosystem and Environment, 40, 71-93. doi:10.1016/0167-8809(92)90085-P

[31] Saska, P. Vodde, M., Heijerman, T., Westerman, P. and van der Werf, W. (2007) The significance of a grassy field boundary for the spatial distribution of carabids within two cereal fields. Agriculture, Ecosystem and Environment, 122, 427-434. doi:10.1016/j.agee.2007.02.013

[32] Lys, J.-A. (1994) The positive influence of strip-management on ground beetles in a cereal field: Increase, migration and overwintering. In: Desender, K., Dufrene, M., Loreau, M., Luff, M.L. and Maelfait, J.P., Eds., Carabid Beetles: Ecology and Evolution, Kluwer Academic Publishers, Dordrecht, 451-455. doi:10.1007/978-94-017-0968-2_68

[33] van Dijk, T.S. (1994) On the relationship between food, reproduction and survival of two carabid beetles: $\mathrm{Ca}$ lathus melanocephalus and Pterostichus versicolor. Ecological Entomology, 19, 263-270. doi:10.1111/j.1365-2311.1994.tb00418.x

[34] Frank, T., Kehrli, P. and Germann, C. (2007) Density and nutritional condition of carabid beetles in wildflower areas of different age. Agriculture, Ecosystem and Environment, 120, 377-383. doi:10.1016/j.agee.2006.10.012

[35] Olson, D.M. And Wäckers, F.L. (2007) Management of field margins to maximize multiple ecological services. Journal of Applied Ecology, 44, 13-21. doi:10.1111/j.1365-2664.2006.01241.x

[36] Salamon, J., Wissuwa, J., Jagos, S., Koblmüller, M., Ozinger, O., Winkler, C. and Frank, T. (2011) Plant species effects on soil macrofauna density in grassy arable fallows of different age. European Journal of Soil Biology, 47, 129-137. doi:10.1016/j.ejsobi.2011.01.004

[37] Thies, C. and Tscharntke, T. (1999) Landscape structure and biological control in agroecosystems. Science, 285, 893-895. doi:10.1126/science.285.5429.893

[38] Smith, J., Potts, S. and Eggleton, P. (2008) The value of sown grass margins for enhancing soil macrofaunal biodiversity in arable systems. Agriculture, Ecosystem and Environment, 27, 119-125. doi:10.1016/j.agee.2008.03.008

[39] Hof, A.R. and Bright, P.W. (2010) The impact of grassy field margins on macro-invertebrate abundance in adjacent arable fields. Agriculture, Ecosystem and Environment, 139, 280-283. doi:10.1016/j.agee.2010.08.014

[40] Thomas, C.F.G. and Marshall, E.J.P. (1999) Arthropod abundance and diversity in differently vegetated margins of arable fields. Agriculture, Ecosystem and Environment, 72, 131-144. doi:10.1016/S0167-8809(98)00169-8

[41] Eyre, M.D., Labanowska-Bury, D., White, R. and Leifert, C. (2011) Relationships between beneficial invertebrates, field margin vegetation, and thrip damage in organic leek fields in eastern England. Organic Agriculture, 1, N45N54. doi:10.1007/s13165-010-0004-X

[42] Collins, K.L., Boatman, N.D., Wilcox, A., Holland, J.M. and Chaney, K. (2002) Influence of beetle banks on ce- 
real aphid predation in winter wheat. Agriculture, Ecosystem and Environment, 93, 337-350. doi:10.1016/S0167-8809(01)00340-1

[43] Lys, J.-A., Zimmermann, M. and Nentwig, W. (1994) Increase in activity and species number of carabid beetles in cereals as a result of strip-management. Entomologia Experimentalis et Applicata, 73, 1-9. doi:10.1111/j.1570-7458.1994.tb01833.x

[44] Gardiner, M.M., Landis, D.A., Gratton, C., Schmidt, N., O'Neal, M., Mueller, E., Chacon, J. and Heimpel, G.E.
(2010) Landscape composition influences the activity density of carabidae and arachnida in soybean fields. Biological Control, 55, 11-19. doi:10.1016/i.biocontrol.2010.06.008

[45] Purtauf, T., Roschewitz, I., Dauber, J., Thies, C., Tscharntke, T. and Wolters, V. (2005) Landscape context of organic and conventional farms: Influences on carabid beetle diversity. Agriculture, Ecosystems and Environment, 108, 165-174. doi:10.1016/j.agee.2005.01.005 